\title{
Some Properties of Xanthomonas campestris pv. campestris Phage
}

\author{
Minoru Watanabe*, Kiyomi Naito**, Kunio KaneKo***, \\ Hitoshi Nabasama**** and Daijiro HosoKa WA* \\ 渡辺 実* - 内藤きよ美** - 金子邦夫*** - 南波佐間 化**** - 細川大二郎*： \\ Xanthomonas campestris pv. campestris ファージの諸性質について
}

\begin{abstract}
Xanthomonas campestris pv. campestris phages ( 3 isolates of phage $\mathrm{S}, \mathrm{K}$ and 76 ) were isolated from black rot diseased leaves of cabbage, cauliflower and turnip, and some of their fundamental properties were investigated. The particle of phage $S$ was tadpole-like with a polyhedral head of about $50 \times 60 \mathrm{~nm}$ and a tail of about $110 \times 10$ to $12 \mathrm{~nm}$. Phages $\mathrm{S}$ and $\mathrm{K}$ attacked specifically $X$. campestris pv. campestris, but not $X$. campestris pv. citri, pv. cucurbitae, pv. oryzae, pv. phaseoli and pv. pruni. Phages $\mathrm{S}$ and $\mathrm{K}$ showed different host range to bacterial isolates of $X$. campestris pv. campestris. The thermal inactivation point of phage $\mathrm{S}$ was $53 \mathrm{C}$ in distilled water and $65 \mathrm{C}$ in potato ring-rot liquid medium by $10 \mathrm{~min}$ incubation. Phage $\mathbf{S}$ was more stable in its lytic activity in potato ring-rot liquid medium or in phosphate buffer than in distilled water. Phage $\mathrm{S}$ was also stable at $\mathrm{pH} 7.0$, but not at $\mathrm{pH} 4.9$ or 9.1. Throughout all conditions of different three dispersants and five $\mathrm{pH}$ levels phage $\mathrm{S}$ was more stable at $5 \mathrm{C}$ than at $28 \mathrm{C}$. One-step growth experiments showed that multiplication of phage ' 76 was optimal at $28 \mathrm{C}$. The latent period, rise period and average burst size in the case of single infection were $75 \mathrm{~min}, 40 \mathrm{~min}$ and 13 plaque forming units, respectively. At $30 \mathrm{C}$ or at the temperatures below $26 \mathrm{C}$, however, the latent period was prolonged and the average burst size became smaller.
\end{abstract}

(Received May 26, 1980)

\section{Introduction}

Black rot disease has caused serious damage to many crucifer plants especially to cabbage and cauliflower at Tama district, Tokyo.

Although many phages which attack corresponding plant pathogenic bacteria have been isolated, only a few reports were found on the phage which attacks Xanthomonas campestris pv. campestris, the causal bacterium of black rot disease of crucifers ${ }^{4,5,18}$. The first report on the morphology, host range and one-step growth of $X$. campestris pv. campestris phage was made by Sutton $e t$ al. ${ }^{18)}$, who showed that the phage attacked a wide range of

* Faculty of Agriculture, Tokyo University of Agriculture and Technology, Fuchu, Tokyo 183, Japan 東京農工大学農学部

** Present address : Hitsujigaoka, Toyohira-ku, Sapporo 061-01, Japan 現在：札幌市豊平区羊ヶ丘1

*** Present address : Meiji Seika Co., Ltd., 2-4-16,Kyobashi, Chuo-ku, Tokyo 104, Japan 現在： 明治製菒㧣

**** Present address: Mikado Breeding Farm, Otaki-cho, Isumi-gun, Chiba Pref. 298-02, Japan 現在：脷みかど育種農場 
Xanthomonas species including $X$. campestris pv. campestris.

Several phage isolates were obtained from black rot diseased leaves, and some fundamental properties of these phages will be described here.

\section{Materials and Methods}

Isolation of host bacteria. X. $\quad$ campestris pv. campestris was isolated from black rot diseased leaves of cauliflower, turnip and cabbage in the experimental farm of Tokyo University of Agriculture and Technology in 1966 and also from diseased leaves of cabbage in 1976 . The pathogenicity of these bacterial isolates was confirmed by the needleprick inoculation to the healthy cabbage leaves.

Isolation and enrichment of phages. Phages were isolated from diseased leaves of cauliflower and turnip in 1966 and from those of cabbage in 1976 by the use of corresponding indicator strain of host bacterium, and they were designated as the phage $\mathrm{S}, \mathrm{K}$ and '76, respectively.

Isolation was made as follows: lesion parts of diseased leaves were homogenized with sterilized distilled water, centrifuged at $7,000 \times \mathrm{g}$ for $15 \mathrm{~min}$ and the supernatant was adequately diluted. The mixtures consisting of diluted supernatant, bacterial suspension of indicator strain and melted bouillon agar medium containing $0.6 \%$ agar were poured onto the basal layer of bouillon agar ( $2 \%$ agar) solidified previously in Petri dish, and were incubated at $28 \mathrm{C}$ for 15 to $20 \mathrm{hr}$.

Small clear plaques of about $1 \mathrm{~mm}$ in diameter appeared as shown in Fig. 1. The phages in a single plaque were transferred into a broth culture of indicator strain in test tubes. After incubation by shake culture for $24 \mathrm{hr}$ at $28 \mathrm{C}$, the bacterial cells were removed by centrifugation at $7,000 \times g$ for $15 \mathrm{~min}$, and small quantities of the supernatant were re-transferred into the fresh bacterial broth culture. After these three serial enrichment of the phage, high titer phage lysates of approximately $10^{9}$ plaque forming units (pfu) per $\mathrm{ml}$ were obtained by the soft agar layer method".

Preparation of anti-phage serum. Phage suspension $\left(2.6 \times 10^{5} \sim 3 \times 10^{8}\right.$ pfu per $\mathrm{ml}$ ), previously eliminated bacterial debris by filtrating with Millipore filter (pore size $0.22 \mu \mathrm{m}$ ), was injected 11 times into the ear vein of rabbit at intervals of 2 to 3 days. Anti-serum was taken by routine method. The K-value (velocity constant of phage inactivation) of this anti-serum was about 50 .

One-step growth experiment. In the experiments of single infection, $1 \mathrm{ml}$ of

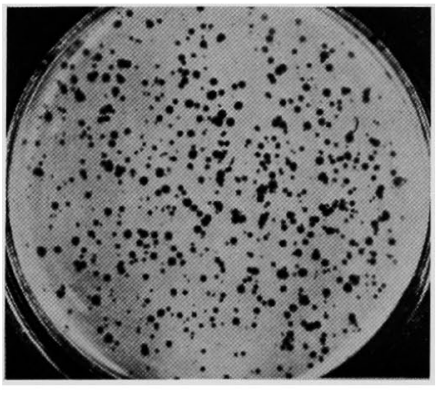

Fig. 1. Plaques of $X$. campestris pv. campestris phage. bacterial suspension $\left(5 \times 10^{8}\right.$ cells per $\left.\mathrm{ml}\right)$ and $1 \mathrm{ml}$ of phage suspension $\left(1 \times 10^{8}\right.$ pfu per $\left.\mathrm{ml}\right)$ were mixed in test tubes kept in a water-bath at $20,22,26,28$ and $30 \mathrm{C}$. After $10 \mathrm{~min}$, free phages were inactivated by adding $4 \mathrm{ml}$ anti-phage serum for $5 \mathrm{~min}$, then $0.5 \mathrm{ml}$ of the mixtures (bacterium-phage complex and anti-serum) was diluted to 10,000-fold with Cavfch medium ${ }^{22}$ (so-called 'growth tube'). Bacterium-phage complex $(0.1 \mathrm{ml})$ was taken out from the growth tube at settled intervals, and used for plaque counting.

In the experiments of multiple infection, $1 \mathrm{ml}$ of 
bacterial suspension (about $10^{7}$ cells per $\mathrm{ml}$ ) and $1 \mathrm{ml}$ of phage suspension (about $10^{8}$ pfu per $\mathrm{ml}$ ) were mixed, and kept at $22,26,28$ and $30 \mathrm{C}$. Other experimental procedures were the same as those in the experiment of single infection.

\section{Results}

\section{Morphology of phage $S$ particle}

Phage $S$ suspension was treated with twice repeating of ultra (at $50,000 \times g$ for 40 $\mathrm{min}$ ) and low speed differential centrifugation (at 7,000 $\mathrm{g}$ for $15 \mathrm{~min}$ ). The phage suspension thus treated was negatively stained with $1 \%$ alcoholic solution of phosphotungstic acid for electron microscopic observation.

This phage particle was typical tadpole-like, with a polyhedral head about $50 \times 60 \mathrm{~nm}$ and a cylindrical tail about $110 \mathrm{~nm}$ in length and about 10 to $12 \mathrm{~nm}$ in diam. (Fig. 2 and 3).

\section{Host range}

Host range was studied by streaking or dropping the phage suspension onto the culture surface of an indicator strain on potato ring-rot agar medium ${ }^{2)}$. After the incubation at $28 \mathrm{C}$ for $20 \mathrm{hr}$, the appearance of lysis was examined (Fig. 4).

Table 1 showed that phages $\mathrm{S}$ and $\mathrm{K}$ did not attack Xanthomonas campestris pv. citri (7 isolates), pv. cucurbitae, pv. oryzae, pv. phaseoli ( 1 isolate of each) and pv. pruni (3 isolates). As to the isolates of $X$. campestris pv. campestris, phage $\mathrm{S}$ lysed 5 bacterial isolates out of 9 tested, whereas phage $\mathrm{K}$ attacked only 2 out of 4 which were not lysed by phage $S$. Therefore, it was clear that phages $S$ and $K$ were complementary in their host range.

\section{Thermal inactivation points of phage $S$}

Phage $\mathrm{S}$ was suspended in distilled water ( $\mathrm{pH} \mathrm{5.4),} \mathrm{phosphate} \mathrm{buffer} \mathrm{(} \mathrm{pH} \mathrm{7.0)}$ and potato ring-rot liquid medium $(\mathrm{pH} 7.0)$ at the density of several hundreds pfu per $0.1 \mathrm{ml}$. One $\mathrm{ml}$ of the suspension was poured into a test tube and was immersed in a water-bath at given temperature. After $10 \mathrm{~min}$ incubation, the test tube was cooled rapidly with running tap water. Then, pfu in $0.1 \mathrm{ml}$ of phage suspension was determined by the

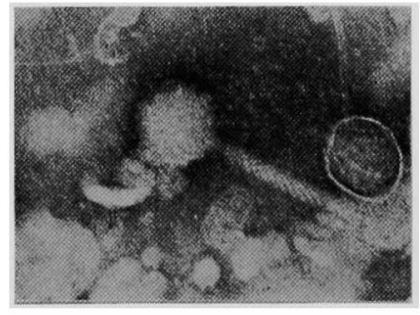

Fig. 2. Electron micrograph of phage $\mathrm{S}$ negatively stained by $1 \%$ phosphotungstic acid (PTA). $\times 150,000$

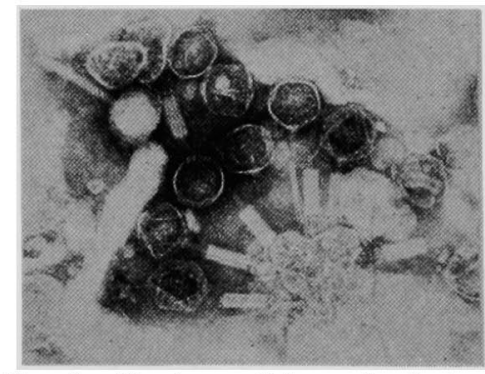

Fig. 3. Ghost particles adsorbed to bacterial debris with its tail. Electron micrograph of phage S negatively stained by $1 \%$ PTA. $\times 100,000$ 


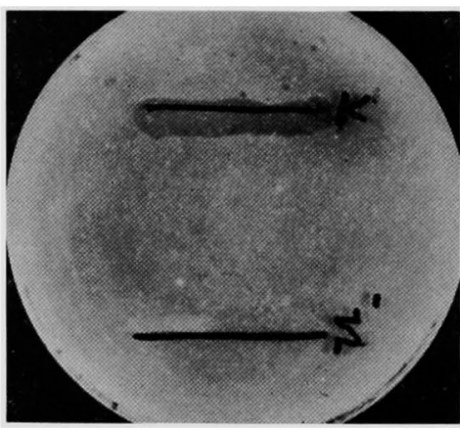

Fig. 4. Host range test of phage isolates. Phage suspension was streaked onto agar surface on which test bacterium was inoculated. One phage isolate (upper line) lysed test bacterium, but the other phage isolate (under line) did not. plaque counting method after incubation at $28 \mathrm{C}$ for 20 hr.

Table 2 showed that the thermal inactivation points of phage $\mathrm{S}$ in distilled water ( $\mathrm{pH}$ 5.4), phosphate buffer $(\mathrm{pH} 7.0)$ and potato ring-rot liquid medium ( $\mathrm{pH} 7.0)$ were $53 \mathrm{C}, 62 \mathrm{C}$ and $65 \mathrm{C}$, respectively by $10 \mathrm{~min}$ treatment.

\section{Time course of phage $S$ inactivation}

Phage $\mathrm{S}$ was suspended in three dispersive solutions mentioned above at the density of 1,000 pfu per $0.1 \mathrm{ml}$. Fifteen $\mathrm{ml}$ of the suspension were poured into test tubes and were incubated at $5 \mathrm{C}$ and $28 \mathrm{C}$. Then, plaque counting was made at the settled intervals.

Table 3 showed that the phages were rapidly inactivated in distilled water at either $28 \mathrm{C}$ or $5 \mathrm{C}$, most of the phage particles was inactivated within 1 to 2 days. Less inactivation was observed in phosphate buffer and potato ring-rot liquid medium, in which more than half

of original pfu was retained even after 10 days at $28 \mathrm{C}$. Furthermore, a tendency was observed that the inactivation was greater at $28 \mathrm{C}$ than at $5 \mathrm{C}$ in all three dispersive solutions tested, especially in distilled water.

The effects of $\mathrm{pH}$ and temperature on the inactivation were investigated with the

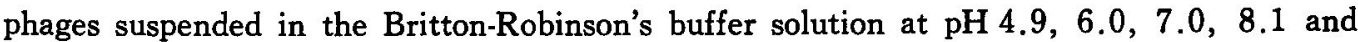
9.1 by similar methods described above.

At $28 \mathrm{C}$, the inactivation was remarkable within 1 day at $\mathrm{pH} 4.9$, but it became less with approaching to the neutral, and was the least at $\mathrm{pH} 7.0$ (Table 4). However, at $\mathrm{pH}$ higher than 7.0, inactivation increased again, and was remarkable after 7 days at $\mathrm{pH}$ 9.1. A similar tendency of inactivation was also observed at $5 \mathrm{C}$, but the phages were found to be more stable at $5 \mathrm{C}$ than at $28 \mathrm{C}$ in any $\mathrm{pH}$ tested.

Table 1. Host ranges of $\mathrm{S}$ and $\mathrm{K}$ phage of $X$. campestris pv. campestris

\begin{tabular}{|c|c|c|c|c|c|c|}
\hline \multirow{2}{*}{\multicolumn{2}{|c|}{ Bacteria }} & \multicolumn{2}{|c|}{$\begin{array}{l}\text { Phage } \\
\text { isolates }\end{array}$} & \multirow[t]{2}{*}{ Bacteria } & \multicolumn{2}{|c|}{$\begin{array}{l}\text { Phage } \\
\text { isolates }\end{array}$} \\
\hline & & $\mathrm{s}$ & $\mathbf{K}$ & & $\mathrm{S}$ & $\mathbf{K}$ \\
\hline$X$. campestris & & & & $X$. campestris & & \\
\hline pv. campestris & -1 & -2 & + & pv. citri (7 isolates) & - & - \\
\hline "I & -2 & - & + & pv. cucurbitae ( 1 isolate) & - & - \\
\hline$" 1$ & -3 & + & - & pv. oryzae ( 1 isolate) & - & - \\
\hline " & -4 & + & - & pv. phaseoli ( 1 isolate) & - & - \\
\hline$"$ & -5 & + & - & pv. pruni ( 3 isolates) & - & - \\
\hline$" \prime$ & -6 & + & - & & & \\
\hline$" 1$ & -7 & + & - & & & \\
\hline$" 1$ & -8 & - & - & & & \\
\hline$" 1$ & -9 & - & - & & & \\
\hline
\end{tabular}

a) + : Lysis occurred, - : not occurred. 
Table 2. Thermal inactivation point of $S$ phage

\begin{tabular}{c|rrrrrr}
\hline \multirow{2}{*}{ Dispersant } & \multicolumn{5}{c}{ Treated temperature (C) } \\
\cline { 2 - 7 } & Room temp. & 51 & 52 & 53 & 54 & 55 \\
\hline Dist. water (pH 5.4) & $514^{\mathrm{b})}$ & 5 & 2 & 0 & 0 & 0 \\
\hline \multirow{2}{*}{\begin{tabular}{c} 
Phosphate buffer (pH 7.0) \\
\cline { 2 - 7 }
\end{tabular}} & Room temp. & 59 & 60 & 61 & 62 & 63 \\
\hline $\begin{array}{c}\text { Potato ring-rot } \\
\text { liquid medium (pH 7.0) }\end{array}$ & Room temp. & 62 & 63 & 64 & 65 & 66 \\
\hline
\end{tabular}

a) Treated by $10 \mathrm{~min}$ incubation.

b) Values are the average plaque numbers among four plates of two replications.

Table 3. Time course of inactivation of $S$ phage in different dispersants

\begin{tabular}{c|c|ccccccccc}
\hline \multirow{2}{*}{ Dispersant } & \multirow{2}{*}{$\begin{array}{c}\text { Temper- } \\
\text { ature }\end{array}$} & \multicolumn{7}{|c}{ Time course (days) } \\
\cline { 3 - 10 } & (C) & 0 & 1 & 2 & 3 & 4 & 5 & 7 & 10 \\
\hline \multirow{2}{*}{\begin{tabular}{c} 
Dist. water (pH 5.4) \\
\cline { 3 - 10 }
\end{tabular}} & 28 & $100^{\mathrm{a})}$ & 4 & 0.3 & 0.5 & 0.1 & 0.2 & 0.07 & 0.03 \\
\hline & 5 & 100 & 42 & 17 & 12 & 9 & 13 & 6 & 2 \\
\hline $\begin{array}{c}\text { Phosphate } \\
\text { buffer (pH 7.0) }\end{array}$ & 28 & 100 & 92 & 80 & 71 & 69 & 65 & 48 & 55 \\
\hline $\begin{array}{c}\text { Potato ring-rot liquid } \\
\text { medium (pH 7.0) }\end{array}$ & 5 & 100 & 94 & 90 & 80 & 86 & 82 & 81 & 78 \\
\hline
\end{tabular}

a) Relative plaque numbers of each time course compared with that of zero time. Based on the average numbers among 9 plates of three replications.

Table 4. Inactivation of $\mathrm{S}$ phage under different conditions of $\mathrm{pH}$ and temperatures

\begin{tabular}{|c|c|c|c|c|c|c|c|c|c|}
\hline \multirow{2}{*}{$\mathrm{pH}$} & \multirow{2}{*}{$\begin{array}{l}\text { Temperature } \\
\text { (C) }\end{array}$} & \multicolumn{8}{|c|}{ Time course (days) } \\
\hline & & 0 & 1 & 2 & 3 & 5 & 7 & 10 & 14 \\
\hline \multirow{2}{*}{4.9} & 28 & $100^{a}$ & 44 & 32 & 17 & 42 & 22 & 16 & 14 \\
\hline & 5 & 100 & 65 & 52 & 61 & 58 & 54 & 48 & 29 \\
\hline \multirow{2}{*}{6.0} & 28 & 100 & 75 & 61 & 50 & 65 & 57 & 57 & 50 \\
\hline & 5 & 100 & 76 & 74 & 75 & 61 & 77 & 70 & 61 \\
\hline \multirow{2}{*}{7.0} & 28 & 100 & 79 & 73 & 61 & 80 & 68 & 61 & 60 \\
\hline & 5 & 100 & 91 & 86 & 88 & 91 & 88 & 81 & 73 \\
\hline \multirow{2}{*}{8.1} & 28 & 100 & 54 & 51 & 59 & 66 & 54 & 64 & 50 \\
\hline & 5 & 100 & 84 & 92 & 81 & 80 & 85 & 78 & 71 \\
\hline \multirow{2}{*}{9.1} & 28 & 100 & 69 & 60 & 46 & 41 & 11 & 4 & 4 \\
\hline & 5 & 100 & 96 & 98 & 91 & 69 & 60 & 56 & 55 \\
\hline
\end{tabular}

a) Relative plaque numbers of each time course compared with that of zero time. Based on the average numbers among 9 plates of three replications. 


\section{Effects of temperature on multiplication of phage ' 76}

In order to clarify the effects of temperature for the multiplication and the growth curve of phage, one-step growth experiment ${ }^{1)}$ was conducted using phage '76 and its indicator bacterial strain under several temperature conditions. One-step growth curve at different temperatures in the case of single infection was shown in Fig. 5, and the latent periods, rise periods and average burst sizes at various temperatures in both single and multiple infection were shown in Table 5.

The results showed that optimal multiplication temperature of this phage was $28 \mathrm{C}$, which coincided with that of host bacterium. The latent period, rise period and average burst size at $28 \mathrm{C}$ were $75 \mathrm{~min}, 40 \mathrm{~min}$ and $13 \mathrm{pfu}$, respectively in the case of single infection, and were $70 \mathrm{~min}, 55 \mathrm{~min}$ and $12 \mathrm{pfu}$, respectively in the case of multiple infection. At the temperatures below $26 \mathrm{C}$ or at $30 \mathrm{C}$, the latent periods were prolonged and the average burst sizes became smaller.

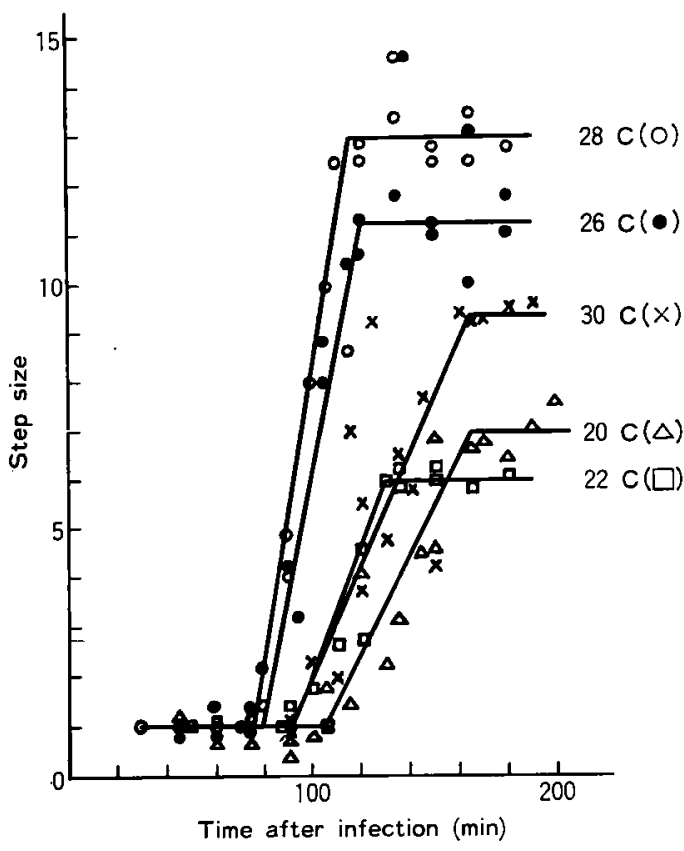

Fig. 5. One-step growth curve of 76 phage at several temperature conditions (single infection). Step size: ratio of pfu at each time to initial pfu at latent period.
Table 5. Results of one-step growth experiments in both single infection and multiple infection of ' 76 phage $^{\text {a) }}$

\begin{tabular}{c|c|c|c|c}
\hline $\begin{array}{l}\text { Temper- } \\
\text { ature } \\
(\mathrm{C})\end{array}$ & $\begin{array}{l}\text { Types } \\
\text { of } \\
\text { infec- } \\
\text { tion }\end{array}$ & $\begin{array}{l}\text { Latent } \\
\text { period } \\
(\mathrm{min})\end{array}$ & $\begin{array}{l}\text { Rise } \\
\text { period } \\
(\mathrm{min})\end{array}$ & $\begin{array}{l}\text { Average } \\
\text { burst } \\
\text { size } \\
\left(\text { pf }^{\mathrm{b})}\right)\end{array}$ \\
\hline 20 & $\mathrm{~S}^{\mathrm{c})}$ & 100 & 60 & 7 \\
\hline 22 & $\mathrm{~S}$ & 90 & 40 & 6 \\
\hline $\mathrm{M}$ & 80 & 55 & 5 \\
\hline 26 & $\mathrm{~S}$ & 80 & 40 & 11 \\
\hline $\mathrm{M}$ & 70 & 60 & 9 \\
\hline 30 & $\mathrm{~S}$ & 75 & 40 & 13 \\
\hline $\mathrm{M}$ & 70 & 55 & 12 \\
\hline $\mathrm{S}$ & 90 & 75 & 9 \\
\hline $\mathrm{M}$ & 90 & 65 & 8 \\
\hline
\end{tabular}

a) Data are the average of duplicated experiments.

b) Plaque forming units.

c) S: single infection. $\mathrm{M}$ : multiple infection.

\section{Discussion}

The polyvirulent Xanthomonas phage $\mathrm{Pg} 125$ was isolated by Sutton et al. ${ }^{18)}$ from a suspension of macerated swede seed, compost and sewage which were added in nutrient broth heavily inoculated with $X$. campestris pv. campestris. $\mathrm{Pg} 125$ was found to attack in vitro numerous phytopathogenic xanthomonads; such as $X$. campestris pv. campestris, 
pv. malvacearum, pv. phaseoli, pv. pruni and pv. vesicatoria, etc. The present phages S and $\mathrm{K}$, however, attacked only a homologous pathovar, $X$. campestris pv. campestris. It has been reported in Japan that phages of $X$. campestris pv. citri ${ }^{8}$, pv. oryza $e^{3,26)}$, pv. pruni $^{19)}$, Pseudomonas syringae pv. mori ${ }^{15)}$, pv. tabaci ${ }^{14)}, P$. solanacearum ${ }^{11)}$ and Erwinia carotovor $^{17)}$ attacked only its homologous species or pathovars; on the other hand, certain phage strains of $X$. campestris pv. campestris ${ }^{4)}$, pv. citri $^{4)}$, pv. translucens f. sp. oryzicola ${ }^{3)}$, $P$. syringae pv. eriobotryae ${ }^{10)}$ and pv. mori ${ }^{16)}$ attacked several heterologous species or pathovars in addition to its homologous ones.

Goto et $a l .^{4)}$ described that Xanthomonas phages which could frequently be found in soil, in general, showed very broad host ranges including many heterologous nomenspecies; in contrast, those which were isolated from diseased plant tissues usually showed limited host ranges. A Xanthomonas campestris pv. campestris phage isolated from diseased cabbage by Goto $^{4)}$ attacked 3 isolates out of 93 isolates of $X$. campestris pv. citri, and also 1 isolate of pv. blepharidis and of pv. phaseoli in addition to pv. campestris. The discrepancy between our results and those by Goto et al. ${ }^{4)}$ may be due to the number of bacterial strains used.

The presence of phage strains which attack the different bacterial strains within a same species has commonly been observed, for instance, $X$. campestris pv. citri phage $\mathrm{CP}_{1}, \mathrm{CP}_{2}{ }^{25}$, pv. oryzae phage $\mathrm{OP}_{1}{ }^{21)}, \mathrm{OP}_{1 \mathrm{n}}{ }^{7)}, \mathrm{OP}_{1 \mathrm{n}}{ }^{24)}, \mathrm{OP}_{2}{ }^{27)}, \mathrm{BP}_{1} \sim \mathrm{BP}_{7}{ }^{3)}$, pv. pruni phage $\mathrm{PP}_{1}{ }^{9,19)}$, $\mathrm{PP}_{1 \mathrm{n} 1}{ }^{19)}, \mathrm{PP}_{1 \mathrm{n} 2}{ }^{19}$, pv. translucens $\mathrm{f}$. $\mathrm{sp}$. oryzicola phage $\mathrm{SP}_{1 \sim 6}{ }^{3)}, P$. syringae $\mathrm{pv}$. eriobotryae phage $\mathrm{EP}_{1 \sim 3^{10}}{ }^{10)}$, pv. mori phage $\mathrm{MP}_{1}, \mathrm{MP}_{1 \mathrm{~h}}{ }^{15}$, pv. tabaci phage No. $1 \sim 4^{14)}, P$. solanacearum phage $^{11,12)}$ and $E$. carotovora phage $\mathrm{Ap}, \mathrm{Bp}, \mathrm{Cp}^{20)}$.

The thermal inactivation point of phage $\mathrm{S}$ was lowest $(53 \mathrm{C})$ in distilled water ( $\mathrm{pH}$ 5.4) and was considerably higher (62 C) in phosphate buffer ( $\mathrm{pH} 7.0)$ and in potato ring-

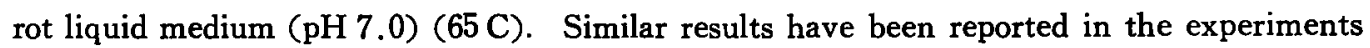
using $X$. campestris pv. oryzae phage $\mathrm{OP}_{1}{ }^{21)}$ and $\mathrm{OP}_{1 \mathrm{n}}{ }^{7)}$, in which the thermal inactivation point was higher in liquid medium than in distilled water. In the case of pv. oryzae phage $\mathrm{OP}_{2}{ }^{27}$, however, no difference was observed between liquid medium and distilled water.

Phage $\mathbf{S}$ was considerably stable in its lytic activity in both phosphate buffer and potato ring-rot liquid medium, but not in distilled water. This result may be related to the difference of thermal inactivation point among dispersants as above mentioned. Phage $\mathrm{S}$ was found to be most stable in a neutral condition ( $\mathrm{pH} \mathrm{7.0)}$ and less stable in both acidic and alkaline conditions ( $\mathrm{pH} 4.9$ and $\mathrm{pH} 9.1$, respectively). Moreover, the phage was more stable at $5 \mathrm{C}$ than at $28 \mathrm{C}$ regardless of the sort of dispersants and $\mathrm{pH}$ values. Similarly, it has been reported that $X$. campestris $\mathrm{pv}$. oryzae phage $\mathrm{OP}_{1}{ }^{21)}$ was unstable under higher temperature and in distilled water. Wakimoto ${ }^{23)}$ reported that if $\mathrm{OP}_{1}$ phage was preserved by freeze drying with protein solution $\left(10^{-2} \sim 10^{-3} \mathrm{~g}\right.$ protein per $\left.\mathrm{ml}\right)$ or with potato semi-synthetic liquid medium, inactivation of phage could be considerably prevented. The reason why phage $\mathrm{S}$ was more stable in potato ring-rot liquid medium than in distilled water might partly be due to the protective action of proteinous components in the former medium.

When compare our results of one-step growth experiment (single infection at $28 \mathrm{C}$ ) with those obtained by Sutton et al. ${ }^{18)}$, latent period was markedly different; that is, $\mathrm{Pg}$ 125 was so long as $210 \mathrm{~min}$, while the present phage '76 was $75 \mathrm{~min}$. An average burst 
size of phage '76 was $13 \mathrm{pfu}$, while $\mathrm{Pg} 125$ was varied from 4 to 12 through three replicated experiments. When compare the characteristics of phage '76 with those of $X$. campestris pv. oryzae phage, latent and rise periods of phage '76 were about two times longer than those of $\mathrm{OP}_{1}$ phage $^{22)}$, and were roughly coincided with those of $\mathrm{OP}_{2}$ phage ${ }^{27}$. It had been reported that $X$. campestris pv. citri phage $\mathrm{CP}_{2}{ }^{6)}$ showed about $150 \mathrm{~min}$ of latent period, and $P$. solanacearum $\mathrm{S}_{1}$ phage $^{13)}$ and $P$. syringae pv. tabaci phage ${ }^{14)}$ showed 190 and $70 \mathrm{pfu}$ of average burst size, respectively.

The present $X$. campestris pv. campestris phages differed apparently in their host range from polyvirulent $\mathrm{Pg} 125$ reported by Sutton et al. ${ }^{18)}$ It will be necessary to clarify further the host range in detail, not only to bacterial strains in $X$. campestris pv. campestris but also to heterologous bacterial species or pathovars by using many phage isolates. Furthermore, the behavior of $X$. campestris pv. campestris in the field should be elucidated by the use of adequate phage isolates.

We wish to express our thanks to Dr. T. Kozaka, Professor of our laboratory, for his kind revision of manuscript. We also thank to Mr. H. Yotsumoto, Mr. K. Kamiyama, Mr. T. Matsuo, Mr. T. Watanabe and Mr. Y. Fukatsu, Japan Electron Optical Ltd., for their kindly taking electron micrographs.

\section{Literature cited}

1. Adams, M. H. (1966). Bacteriophages. Interscience Publishers, New York. pp. 592.

2. Asuyama, H., Mukoh, H. and Suzuki, N. (eds.) (1962). Experimental Methods for Plant Pathology (in Japanese). Japan Plant Protection Assoc., Tokyo. p. 774.

3. Goto, M. (1965). Ann. Phytopath. Soc. Japan 30: 253-257.

4. Goto, M. and Starr, M. P. (1972). Ibid. 38: 226-248.

5. Goto, M. and Yogi, K. (1978). Ibid. $44: 60$ (Abstr. in Japanese).

6. Hidaka, J. and Asakawa, K. (1967). Proc. Assoc. Plani Prot. Kyushu 13: 43-45 (in Japanese).

7. Ikari, H. and Wakimoto, S. (1958). Ibid. $4: 38-40$ (in Japanese).

8. Matsumoto, T. and Okabe, N. (1937). Nogyo oyobi Engei $12: 2055-2059$ (in Japanese with English summary).

9. Mizukami, T. and Ikari, H. (1955). Agric. Bull. Saga Univ. 5 : 33-41 (in Japanese with English summary).

10. Morita, A. (1974). Ann. Phytopath. Soc. Japan 40: 401-411 (in Japanese with English summary).

11. Okabe, N. and Goto, M. (1952). Bull. Fac. Agric. Shizuoka Univ. $2: 64-93$ (in Japanese with English summary).

12. Okabe, N. and Goto, M. (1953). Ibid. 3: 52-80 (in Japanese with English summary).

13. Okabe, N. and Goto, M. (1953). Ibid. 3: 81-100 (in Japanese with English summary).

14. Ono, K. (1976). Bull. Morioka Tobacco Exp. Stn. 11: 1-52 (in Japanese with English summary).

15. Sato, M., Takahashi, K. and Wakimoto, S. (1971). Ann. Phytopath. Soc. Japan 37 : 128-135 (in Japanese with English summary).

16. Sato, M. and Takahashi, K. (1976). J. Sericult. Sci. Japan $45:$ 150-155 (in Japanese with English summary).

17. Shiomi, T. and Fujii, H. (1972). Ann. Phytopath. Soc. Japan 38: 199 (Abstr. in Japanese).

18. Sutton, M. D., Katznelson, H. and Quadling, C. (1958). Canad. J. Microbiol. 4: 493-497.

19. Takanashi, K. (1978). Bull. Fruit Tree Res. Stn. A 5: 1-71 (in Japanese with English summary).

20. Togashi, J. (1976). Bull. Yamagata Univ. Agr. Sci. 7: 31-50 (in Japanese with English summary).

21. Wakimoto, S. (1954). Sci. Bull. Fac. Agr. Kyushu Univ. $14:$ 485-493 (in Japanese with English 
summary).

22. Wakimoto, S. (1955). Ibid. 15 : 151-160 (in Japanese with English summary).

23. Wakimoto, S. (1957). Ann. Phytopath. Soc. Japan 22: 243-250 (in Japanese with English summary).

24. Wakimoto, S. (1960). Ibid. $25: 193-198$.

25. Wakimoto, S. (1967). Ibid. $33: 301-310$.

26. Yoshii, H., Yoshida, T. and Matsui, C. (1953). Ibid. $17: 177$ (Abstr. in Japanese).

27. Yoshimura, S., Saito, T., Yoshino, M. and Morihashi, T. (1960). Proc. Assoc. Plant Prot. Hokuriku 8: 15-20 (in Japanese).

\title{
和 文 摘 要
}

\section{Xanthomonas campestris pv. campestris \\ ファージの諸性質について}

\author{
渡辺 実・内藤き上美・金子邦夫・ \\ 南波佐間 生・細川大二郎
}

アブラナ科植物黒腐病菌のファージ 3 系統 ( $\mathrm{S}, \mathrm{K}$ および'76ファージ) をカンラン, 八ナヤサイ，カブの

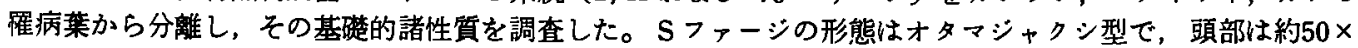

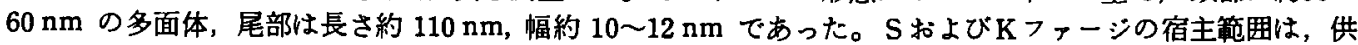
試 Xanthomonas 属細菌のらちアブラナ科植物黒腐病菌のみを侵し，その他のカンキッかいよら病菌，カボ チャ褐斑細菌病菌，イネ白葉枯病菌，インゲン葉焼病菌，核果類せん孔細菌病菌は侵さなかった。また，

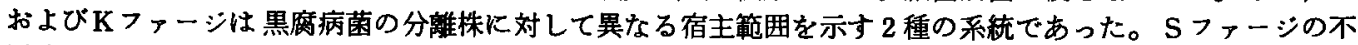
活化温度は蒸留水中では53C，10分間と最す低く，ジャガイモ輪腐病菌液体培地中では65C, 10分間で，かな

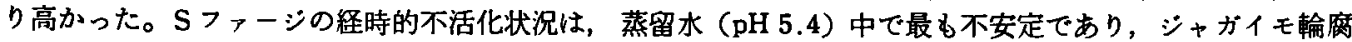
病菌液体培地およびりん酸緩衝液（とむに pH 7.0）中ではかなり安定であった。異なる $\mathrm{pH} の$ 緩衝液中で は pH 7.0 で最も安定であり，pH 4.9 および $\mathrm{pH} 9.1$ では不安定であった。上記 3 種の分散媒沶よび 5 種 の $\mathrm{pH}$ の緩衝液中で, $S$ ファージは28Cより $5 \mathrm{C} て ゙$ 安定であった。数段階の温度条件下での一段増殖実験の 結果から, ’76ファージの增殖には28Cが最適であり，単数感染の場合に潜伏期 75 分間，上昇期 40 分間，新生 ファージ平均放出数13であった。温度が $30 \mathrm{C}$ ，あるいは26C以下のときは28Cの場合より潜伏期が長びき， 新生ファージ平均放出数は小となった。 